\title{
The role of interleukin- 6 in pathogenesis of chronic periapical lesions
}

\author{
Jelena Popović ${ }^{1}$, Tatjana Cvetković2, Tanja Džopalić3, Marija Nikolić1, Aleksandar Mitić1, \\ Radomir Barac', Slavoljub Živković ${ }^{4}$ \\ ${ }^{1}$ University of Nišs, Faculty of Medicine, Clinic of Dentistry, Department of Restorative Dentistry and Endodontics, Nišs, Serbia; \\ ${ }^{2}$ University of Nišs, Faculty of Medicine, Institute of Biochemistry, Nišs, Serbia; \\ ${ }^{3}$ University of Niš, Faculty of Medicine, Institute of Immunology, Nišs, Serbia; \\ ${ }^{4}$ University of Belgrade, School of Dental Medicine, Clinic of Restorative Odontology and Endodontics, Belgrade, Serbia
}

\begin{abstract}
SUMMARY
Introduction Cytokine network plays an important role in pathogenesis of chronic periapical lesions. The aim of this study was to determine the concentration of interleukin-6 (IL-6) in tissue homogenates of human periapical lesions and correlate its levels with symptomatology and size of the lesions.

Materials and Methods 93 samples of chronic periapical lesions were obtained after extraction of teeth. Samples were divided according to the clinical presentation as symptomatic and asymptomatic, and according to the size as large and small. The concentration of IL- 6 was analyzed using ELISA.

Results Statistically significant difference in IL-6 concentration was observed in symptomatic lesions compared to asymptomatic $(\mathrm{p}<0.001)$. Analysis showed statistically higher concentration in large symptomatic lesions compared to large asymptomatic lesions $(p<0.001)$, and in small symptomatic lesions compared to small asymptomatic $(p<0.05)$. Higher production of IL- 6 was observed in large lesions compared to small but this difference was not statistically significant.
\end{abstract}

Conclusion Higher concentration of IL-6 in lesions with expressed clinical symptoms as well as in large lesions indicates that IL- 6 is an important factor responsible for the progression of lesions and bone resorption.

Keywords: Periapical lesions; cytokines; IL-6

\section{INTRODUCTION}

Periapical lesions are inflammatory disorders that develop as a result of an immune response to continuous antigen stimulation from the root canal. Their development and progression to chronic lesions with concomitant bone resorption occur as a result of inability of host defense mechanisms to remove infection [1]. Chronic periapical lesions represent inflamed granulation tissue infiltrated by different inflammatory cells, which produce a variety of mediators. Cytokine network plays an important role in the regulation of non-specific and specific immune responses. Many studies have demonstrated the production of various cytokines in the periapical lesions $[2,3]$.

Interleukin 6 (IL-6) is a cytokine that influences the antigen-specific immune responses and inflammatory reactions, and has the role of proinflammatory and antiinflammatory cytokine [4]. IL-6 is the "myokin", a cytokine produced in the muscles in response to contraction. It increases significantly with exercise, and prior to the occurrence of other cytokines in the bloodstream. IL-6 production is proven in human periapical lesions [5] and in marginal inflamation of periodontal tissues [6]. The literature data suggests that IL- 6 is multifunctional cytokine produced by several types of immune cell- monocytes, macrophage, Th-2 cells, activated B cells, and polymorphonuclear cells [7]. Production of IL-6 is carried out under the influence of IL-1, TNF- $\alpha$ and INF- $\gamma$, however, it also regulates the secretion of IL- 1 and is opposed by some of its effects. IL-6 is secreted by osteoblasts during stimulation of osteoclast formation. IL-6 stimulates the formation of osteoclast precursors and increases the number of osteoclasts in vivo, leading to systematic bone resorption [8]. Along with TNF- $\alpha$ and IL-1, it belongs to the group of major proinflammatory cytokines. Numerous data indicate that IL-6 also has anti-inflammatory activity. The antiinflammatory role of IL-6 is mediated through the inhibitory effects of TNF- $\alpha$ and IL-1 [9].

The aim of this study was to determine the concentration of interleukin-6 (IL-6) in tissue homogenates of human periapical lesions and correlate its levels with symptomatology and size of the lesions.

\section{MATERIALS AND METHODS}

The study included 93 patients from the Clinic of Dentistry, Nis, who were diagnosed with chronic periapical lesions using clinical and radiographic methods. The study was approved by the Ethical Committee of the Medical 
Table 1. Periapical lesions according to symptomatology and size Tabela 1. Podela ispitivanih lezija u grupe prema simptomatologiji i veličini

\begin{tabular}{|l|c|c|c|}
\hline & $\begin{array}{c}\text { Large lesions } \\
\text { Velike lezije }\end{array}$ & $\begin{array}{c}\text { Small lesions } \\
\text { Male lezije }\end{array}$ & $\begin{array}{c}\text { Total } \\
\text { Ukupno }\end{array}$ \\
\hline $\begin{array}{l}\text { Symptomatic lesions } \\
\text { Simptomatske lezije }\end{array}$ & 23 & 23 & 46 \\
\hline $\begin{array}{l}\text { Asymptomatic lesions } \\
\text { Asimptomatske lezije }\end{array}$ & 23 & 24 & 47 \\
\hline $\begin{array}{l}\text { Total } \\
\text { Ukupno }\end{array}$ & 46 & 47 & 93 \\
\hline
\end{tabular}

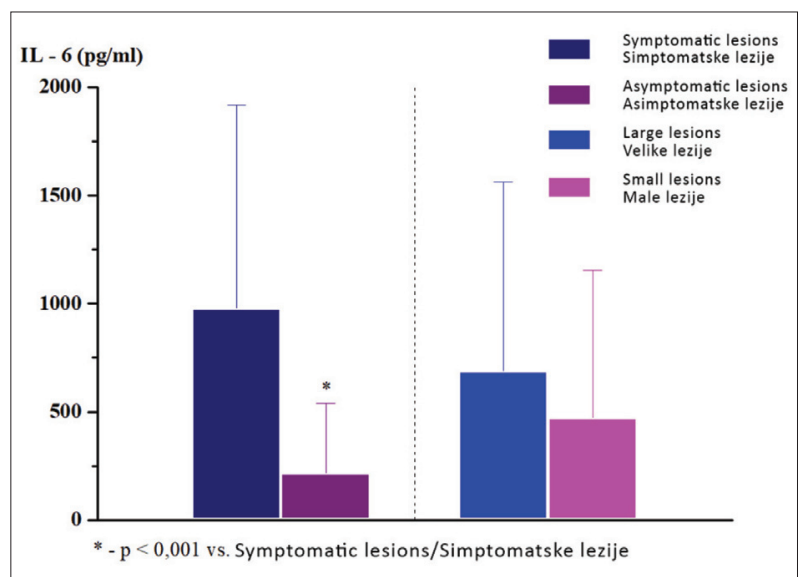

Figure 1. Concentration of IL- 6 in tissue homogenates of periapical lesions in relaton to symptomatology and size

SLika 1. Koncentracija IL-6 u homogenatu tkiva periapeksnih lezija u odnosu na simptomatologiju i veličinu

Faculty, University of Nis, Serbia (no. 01-2066-5). Periapical lesions were collected from teeth that were determined as non-salvageable and indicated for extraction.

From each patient, dental history including symptomatology and medications was collected and clinical exam was performed. Other inclusion criteria were healthy patients not suffering from acute or chronic diseases that could lead to immunodeficiency, and who were not taking antibiotics and anti-inflammatory medications in the last two months.

Only teeth with periapical lesions that did not show moderate or severe form of marginal periodontitis were included in the study. According to subjective symptoms of patients, lesions were divided into the two groups: symptomatic and asymptomatic. Clinically symptomatic lesions were characterized by swelling, pain, discomfort when chewing or sensitivity to percussion and palpation whereas asymptomatic lesions showed no symptoms. The size of periapical lesions was measured in millimeters using a ruler and divided into the two groups: small $(\leq 5$ $\mathrm{mm}$ ) and large $(\geq 6 \mathrm{~mm})$ (Table 1). Since periapical lesions contain granulomatous inflammatory tissue that replaces normal bone there was no equivalent tissue that could be used as negative control.

Before administering local anaesthetics, teeth, gingiva and mucosa around the tooth were cleaned using $0.12 \%$ chlorhexidine and the patient rinsed mouth with $0.12 \%$ chlorhexidine for 30 seconds. Samples of periapical lesions removed from the root apex were collected immediately after the extraction using sterile scalpel, then washed in sterile saline solution, dried with sterile cotton, placed
Table 2. IL-6 concentration in symptomatic and asymptomatic lesions

Tabela 2. Koncentracija IL-6 u okviru grupa simptomatskih i asimptomatskih lezija

\begin{tabular}{|l|c|c|c|c|}
\hline $\begin{array}{l}\text { Symptomatic } \\
\text { Simptomatske }\end{array}$ & $\begin{array}{c}\mathbf{n} \\
\mathbf{n}\end{array}$ & $\begin{array}{c}\text { Mean } \pm \text { SD } \\
\text { Sr. vr. } \pm \text { SD }\end{array}$ & $\begin{array}{c}\text { Median } \\
\text { Mediana }\end{array}$ & $\begin{array}{c}\text { Min.-Max. } \\
\text { Min.-Max. }\end{array}$ \\
\hline $\begin{array}{l}\text { Large lesions } \\
\text { Velike lezije }\end{array}$ & 22 & $1162.40 \pm 1002,40$ & 884.90 & $8.79-2649.63$ \\
\hline $\begin{array}{l}\text { Small lesions } \\
\text { Male lezije }\end{array}$ & 19 & $759.11 \pm 836.24$ & 427.30 & $17.28-2423.72$ \\
\hline $\begin{array}{l}\text { Asymptomatic } \\
\text { Asimptomatske }\end{array}$ & 21 & $189.24 \pm 205.39$ & 74.90 & $27.35-759.62$ \\
\hline $\begin{array}{l}\text { Large lesions } \\
\text { Velike lezije }\end{array}$ & 23 & $232.86 \pm 408.21$ & 107.57 & $11.07-1670.97$ \\
\hline $\begin{array}{l}\text { Small lesions } \\
\text { Male lezije }\end{array}$ & 23 &
\end{tabular}

in a sterile plastic Eppendorf tubes and frozen at $-70^{\circ} \mathrm{C}$. Using teflon crusher in an iced phosphate buffer at $\mathrm{pH}$ 7.4 , samples were homogenized with volume adapted to weight of the tissue obtaining the final concentration of $10 \%$. Larger debris was sedimented by centrifugation at $1400 \mathrm{rpm}$ for 1 minute at $-40^{\circ} \mathrm{C}$. The supernatant was frozen at $-70^{\circ} \mathrm{C}$ until further analysis was performed.

The concentration of IL- 6 was measured using ELISA test (R\&D Systems Inc. Minneapolis, USA) according to the manufacturer's instructions. The sensitivity of ELISA test for IL-6 was from $0.7 \mathrm{pg} / \mathrm{ml}$, and the concentration of cytokine was analyzed in relation to the size and symptomatology of periapical lesions. Statistical analysis was performed using the Mann-Whitney Rank Sum test in the software Sigmastat and Origin. The results were expressed as mean \pm standard deviation. $P<0.05$ was considered statistically significant.

\section{RESULTS}

All tissue homogenates of periapical lesions showed significant concentration of IL- 6 cytokine. Figure 1 shows the concentration of IL-6 in the tissue homogenates of all samples that were analyzed with respect to the size and symptomatology. In symptomatic lesions average concentration of IL-6 was $975.51 \mathrm{pg} / \mathrm{ml}$, while in the group of asymptomatic lesions the average value was $212.04 \mathrm{pg} / \mathrm{ml}$. Analysis of the concentration showed that there was significantly higher concentration of IL- 6 in symptomatic lesions $(p<0.001)$. In the group of large lesions, average concentrations of IL- 6 amounted to $687.14 \mathrm{pg} / \mathrm{ml}$, while in the group of small lesions average value was $470.92 \mathrm{pg} / \mathrm{ml}$. The difference was observed but not statistically significant.

Table 2 shows the concentration of IL- 6 within the group of symptomatic and asymptomatic lesions, and the concentration of cytokines in each of the groups were analyzed with respect to the size. The average concentration of IL-6 in the large symptomatic lesions amounted to $1162.40 \mathrm{pg} / \mathrm{ml}$, while in the small symptomatic lesions it was $759.11 \mathrm{pg} / \mathrm{ml}$. A statistically significant difference in the concentrations of IL- 6 was not observed in the symptomatic lesions in relation to the size. In the group of asymptomatic lesions, statistically significant differ- 


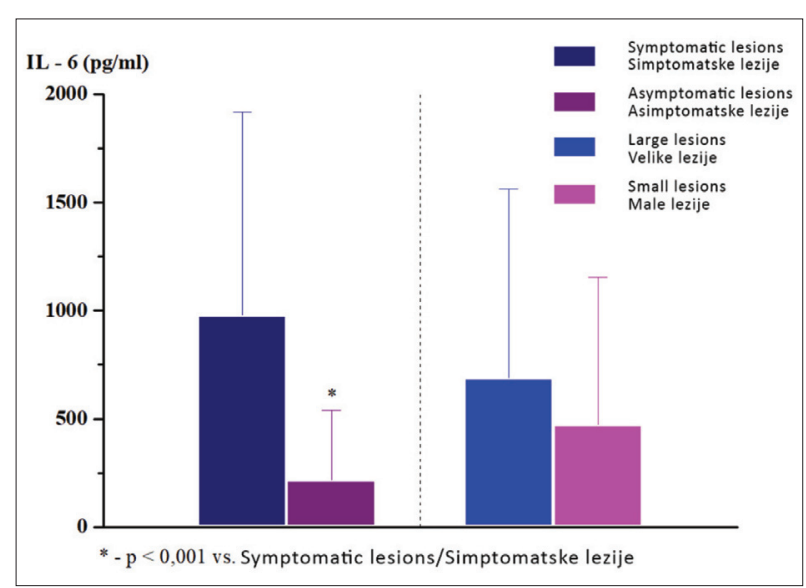

Figure 2. IL-6 concentration in large and small lesions Slika 2. Koncentracija IL-6 u okviru grupa velikih i malih lezija

ence in concentration of IL- 6 was also not observed in relation to the size. The average concentration of IL-6 in large asymptomatic lesions amounted to $189.24 \mathrm{pg} / \mathrm{ml}$, while in small asymptomatic lesions it was $232.86 \mathrm{pg} / \mathrm{ml}$.

Figure 2 shows the concentration of IL- 6 in the groups of large and small lesions where the statistical significance was analyzed in relation to symptomatology. The average concentration of IL- 6 in large symptomatic lesions amounted to $1162.40 \mathrm{pg} / \mathrm{ml}$, while in large asymptomatic lesions it was $189.24 \mathrm{pg} / \mathrm{ml}$. The difference was statistically significant $(\mathrm{p}<0.001)$. The analysis showed significantly higher concentration in small symptomatic (759.11 $\mathrm{pg} / \mathrm{ml}$ ) compared to small asymptomatic lesions (232.86 $\mathrm{pg} / \mathrm{ml})(\mathrm{p}<0.05)$.

\section{DISCUSSION}

Periapical lesions develop as a result of persistent inflammatory response induced by prolonged exposure of periapical tissue to root canal microorganisms, causing an immune reaction. In this local defense mechanism different inflammatory mediators play a complex and central role in the regulation of immune response. While proinflammatory cytokines, such as IL-1, IL- 6 , TNF- $\alpha$, TNF- $\beta$, chemokines and Th1 cytokines, promote inflammation in the periapical tissues and activate osteoclastic bone resorption $[10,11]$, the role of antiinflammatory cytokines is important for suppression of inflammatory processes and repair processes within the periapical lesions $[2,3,12]$.

In the early inflammatory cascade IL- 1 and TNF- $\alpha$ induce production of IL-6. IL-6 has many molecular forms, and each molecule has a different function if secreted by various cells in different situations. The finding that polymorphonuclear cells in the periapical tissues produce IL-6, which was specified by the Euler et al. [13], suggest that IL- 6 can contribute to the tissue injury at the site of inflammation. IL-6 is an integral mediator of the acute phase response to injury and infection that stimulate expression of acute phase protein [14]. Examination of various cytokines, such as TNF- $\alpha$, IL-6, IL-3, GM-CSF, IL-11, IL-17, IL-18, in human and animal models have demonstrated their potential role in the pathogenesis of osteo- lytic diseases $[2,15]$. It has been shown that inflammatory cytokines IL- 6 and TNF- $\alpha$ have the capacity to trigger osteoclastic bone resorption and their role can express synergistically with IL-1, causing activation or osteoclast differentiation and production, as well as secretion of prostaglandins by numerous cell types, including fibroblasts and osteoblasts [2]. Several authors have published the expression of IL-6 production in human periapical granulomas and cysts. Results of our study showed the presence of IL- 6 in all tissue samples of periapical lesions that is in accordance with data from the literature $[9,16]$.

Studies have shown that the level of IL- 6 is significantly increased in the infection and pain conditions. In the study of De Jongh et al. [17] important role is attributed to IL-6 in the pathophysiology of pain. Due to this fact, in our study we analyzed correlation between levels of IL- 6 and symptomatology. The results of our investigations indicated statistically significant difference in IL-6 production in the symptomatic compared to asymptomatic lesions, while the average concentration of cytokines was higher in the large lesions compared to small, but the difference was not statistically significant.

The study of Gazivoda et al. [18] showed higher production of IL-6 in symptomatic and large lesions primarily emphasizing its proinflammatory aspect. However, experiments on IL-6-deficient mice showed conflicting results, indicating protective effect of this cytokine to bone destruction [14]. These differences may be explained by the fact that IL- 6 has both proinflammatory and antiinflammatory role and its final effect depends on the target cells and coordination with additional cytokines.

Inflammatory reaction in patients with apical periodontitis is not limited to periradicular region [19]. It is known that dental infection can have negative impact on general health in patients with risk [20]. Blood analysis in patients after endodontic treatment of teeth with apical periodontitis showed the presence of bacteria that originate from root canal [21]. Spreading oral bacteria through the bloodstream is not the only way for mediation-targeted effects of oral focal infections. More significant effect on distant tissues and organs function may be induced by certain cytokines. Although the majority of members of the cytokine superfamily exhibits short-term effects, IL1, IL-6 and TNF have been shown that locally produced within the tissues of periapical granulomas, can be carried by the bloodstream to distant places. These cytokines can cause acute phase response, which includes fever, increased erythrocyte sedimentation rate, and change in serum proteins synthesized by hepatocytes. Some authors examined elevated levels of acute phase protein in patients with chronic periapical granulomas. Their level was lowered to the normal value after the surgical removal of lesions by apicoectomy [10,22].

\section{CONCLUSIONS}

High concentration of IL-6 in lesions with expressed clinical symptoms, as well as in large lesions, indicate its important pro-inflammatory activity and key role of 
strong mediator responsible for the progression of lesion and stimulation of bone resorption in the pathogenesis of periapical lesions.

\section{REFERENCES}

1. Walker KF, Lappin DF, Takahashi K, Hope J, Macdonald DG, Kinane DF. Cytokine expression in periapical granulation tissue as assessed by immunohistochemistry. Eur J Oral Sci 2000; 108:195-201. [DOI: 10.1034/j.1600-0722.2000.108003195.x] [PMID: 10872989]

2. Danin J, Linder LE, Lundqvist G, Andersson L. Tumor necrosis factor-alpha and transforming growth factor-beta1 in chronic periapical lesions. Oral Surg Oral Med Oral Pathol Oral Radiol Endod. 2000; 90:514-17. [DOI: 10.1067/moe.2000.108958] [PMID: 11027390]

3. Čolić M, Gazivoda D, Vučičević D, Vasilijić S, Rudolf R, Lukić A. Prionflammatory and immunoregulatory mechanisms in periapical lesions. Mol Immunol. 2009; 47:101-13.

[DOI: 10.1016/j.molimm.2009.01.011] [PMID: 19232436]

4. Heinrich PC, Behrmann I, Haan S, Hermanns HM, Müller-Newen G, Schaper F. Principles of interleukin-6-type cytokine signalling and its regulation. Biochem J. 2003; 374:1-20. [DOI: 10.1042/bj20030407] [PMID: 12773095]

5. De Sá AR, Pimenta FJGS, Dutra WO, Gomez RS. Immunolocalization of interleukin 4, interleukin 6, and lymphotoxin a in dental granuloma. Oral Surg Oral Med Oral Pathol Oral Radiol Endod. 2003; 96:356-60. [DOI: 10.1016/S1079-2104(03)00067-2] [PMID: 12973294]

6. Yamazaki K, Nakajima T, Gemmell E, Polak B, Seymour G), Hara K. IL-4 and IL-6-producing cells in human periodontal disease tissue. J Oral Pathol Med. 1994; 23:347-53.

[DOI: 10.1111/j.1600-0714.1994.tb00074.x]

7. Abdolsamadi HR, Vahedi M, Esmaeili F, Nazari S, Abdollahzadeh S. Serum interleukin-6 as a serologic marker of chronic periapical lesions: A case-control study. J Dent Res Dent Clin Dent Prospects. 2008; 2:43-7. [DOI: 10.5681/joddd.2008.009]

8. Azuma MM, Samuel RO, Gomes-Filho JE, Dezan-Junior E, Cintra LTA. The role of IL-6 on apical periodontitis: a systematic review. Int Endod J. 2014; 47:615-21. [DOI: 10.1111/iej.12196] [PMID: 24224782]

9. Prso IB, Kocjan W, Simić H, Brumini G, Pezelj-Ribarić S, Borcić J, et al. Tumor necrosis factor-alpha and interleukin 6 in human periapical lesions. Mediators Inflamm. 2007; 2007:38210. [DOI: 10.1155/2007/38210] [PMID: 17497030]

10. Márton IJ, Kiss C. Protective and destructive immune reactions in apical periodontitis. Oral Microbiol Immunol. 2000; 15:139-50. [DOI: 10.1034/j.1399-302x.2000.150301.x] [PMID: 11154396]
11. Nair PNR. Pathogenesis of apical periodontitis and the causes of endodontic failures. Crit Rev Oral Biol Med. 2004; 15:348-81. [DOI: 10.1177/154411130401500604] [PMID: 15574679]

12. Kawashima N, Stashenko P. Expresion of bone-resorpting and regulatory cytokines in murine periapical inflammation. Arch Oral Biol. 1999; 44:55-66. [DOI: 10.1016/S0003-9969(98)00094-6] [PMID: 10075151]

13. Euler G), Miller GA, Hutter JW, D'Alessandro MM. Interleukin-6 in neutrophils from peripheral blood and inflammatory periradicular tissues. J Endod. 1998; 24:480-4.

[DOI: 10.1016/S0099-2399(98)80051-4] [PMID: 9693575]

14. Balto K, Sasaki H, Stashenko P. Interleukin-6 deficiency increases inflammatory bone destruction. Infection and Immunity 2001; 69:744-50. [DOI: 10.1128/IAI.69.2.744-750.2001] [PMID: 11159963]

15. Silva TA, Garlet GP, Lara VS, Martins W, Silva JS Cunha FQ. Differential expresion of chemokines and chemokine receptors in inflammatory periapical diseases. Oral Microbiol Immunol. 2005; 20:310-6. [DOI: 10.1111/j.1399-302X.2005.00232.x] [PMID: 16101967]

16. Barkhordar RA, Hayashi C, Hussain MZ. Detection of interleukin-6 in human dental pulp and periapical lesions. Endod Dent Traumatol. 1999; 15:26-7. [DOI: 10.1111/j.1600-9657.1999.tb00744.x] [PMID: 10219150]

17. De Jongh RF, Vissers KC, Meert TF, Booij LHDJ, De Deyne CS, Heylen RJ. The role of interleukin-6 in nociception and pain. Anesth Analg. 2003; 96:1096-103. [DOI: 10.1213/01.ANE.0000055362.56604.78] [PMID: 12651667]

18. Gazivoda D, Dzopalic T, Bozic B, Tatomirovic Z, Brkic Z, Colic M. Production of proinflammatory and immunoregulatory cytokines by inflamatory cells from periapical lesions in culture. J Oral Pathol Med. 2009; 38:605-11. [DOI: 10.1111/j.1600-0714.2009.00788.x] [PMID: 19453841]

19. Gomes MS, Blattner TC, Filho MSA et al. Can apical periodontitis modify systemic levels of inflammatory markers? A systematic review and meta-analysis. J Endod. 2013; 1205-17. [DOI: 10.1016/j.joen.2013.06.014] [PMID: 24041380]

20. Stashenko P, Teles R, D'Souza R. Periapical inflammatory responses and their modulation. Crit Rev Oral Biol Med. 1998; 9:498-521. [DOI: 10.1177/10454411980090040701] [PMID: 9825224$]$

21. Debelian G), Olsen I, Tronstad L. Electrophoresis of whole-cell soluble proteins of microorganisms isolated from bacteriemias in endodontic therapy. Eur J Oral Sci. 1996; 104:540-6. [DOI: 10.1111/j.1600-0722.1996.tb00139.x] [PMID: 9021323]

22. Stashenko P. Role of immune cytokines in the pathogenesis of periapical lesions. Endod Dent Traumatol. 1990; 6:89-96. [DOl: 10.1111/j.1600-9657.1990.tb00400.x] [PMID: 2079017]

Received: $10.04 .2018 \cdot$ Accepted: 18.07 .2018 


\title{
Uloga interleukina-6 u patogenezi hroničnih periapeksnih lezija
}

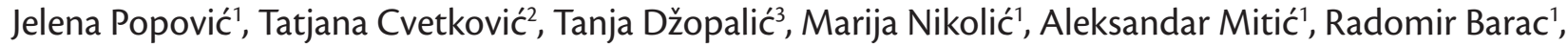 \\ Slavoljub Živković ${ }^{4}$ \\ 'Univerzitet u Nišu, Medicinski fakultet, Klinika za stomatologiju, Služba za bolesti zuba i endodonciju, Niš, Srbija; \\ ${ }^{2}$ Univerzitet u Nišu, Medicinski fakultet, Institut za biohemiju, Nišs, Srbija; \\ ${ }^{3}$ Univerzitet u Nišu, Medicinski fakultet, Institut za imunologiju, Niš, Srbija; \\ ${ }^{4}$ Univerzitet u Beogradu, Stomatološki fakultet, Klinika za bolesti zuba, Beograd, Srbija
}

\begin{abstract}
KRATAK SADRŽAJ
Uvod Mreža citokina igra značajnu ulogu u patogenezi hroničnih periapeksnih lezija. Cilj studije je bio da se odredi koncentracija IL-6 u tkivnim homogenatima hroničnih periapeksnih lezija i da se proveri korelacija sa simptomatologijom i veličinom lezija.

Materijal i metode Ispitana su 93 uzorka hroničnih periapeksnih lezija dobijenih nakon ekstrakcije zuba. Uzorci lezija su podeljeni prema simptomatologiji pacijenata na simptomatske i asimptomatske, a prema veličini na velike i male. Koncentracija IL-6 je ispitivana pomoću ELISA testa, a dobijene vrednosti su analizirane u odnosu na grupe.

Rezultati Statistički značajna razlika u koncentraciji IL-6 je uočena u grupi simptomatskih lezija u poređenju sa asimptomatskim $(p<0,001)$. Analiza je pokazala i statistički značajno veću koncentraciju u velikim simptomatskim lezijama u odnosu na velike asimptomatske $(p<0,001)$ i u malim simptomatskim lezijama u odnosu na male asimptomatske $(p<0,05)$. Zapažena je i povećana produkciju IL-6 u velikim lezijama u odnosu na male, međutim, razlika nije bila statistički značajna.

Zaključak Veća koncentracija IL-6 u lezijama sa izraženim kliničkim simptomima kao i velikim lezijama ukazuje na njegovu važnu ulogu u progresiji periapeksnih lezija i koštane resorpcije.

Ključne reči: periapeksne lezije; citokini; IL-6
\end{abstract}

\section{UVOD}

Periapeksne lezije su inflamatorna oboljenja koja nastaju kao rezultat imunog odgovora na kontinuiranu antigenu stimulaciju iz kanala korena. Njihov razvoj i progresija u hronične lezije sa posledičnim gubitkom kosti nastaju kao rezultat nemogućnosti mehanizama odbrane domaćina da ukloni infekciju [1]. Tkivo hroničnih periapeksnih lezija predstavlja inflamirano granulaciono tkivo infiltrisano različitim inflamatornim ćelijama koje produkuju brojne medijatore. Mreža citokina ima značajnu ulogu u regulisanju nespecifičnih i specifičnih imunih odgovora. Mnoge studije su dokazale produkciju različitih citokina u periapeksnim lezijama [2,3].

Interleukin 6 (IL-6) je citokin koji utiče na antigen-specifične imune odgovore i inflamatorne reakcije i ima ulogu i proinflamatornog i antiinflamatornog citokina [4]. IL-6 je i „miokin“, citokin produkovan u mišićima u odgovoru na mišićnu kontrakciju. Značajno se povećava vežbanjem, a prethodi i pojavi drugih citokina u cirkulaciji. IL-6 je dokazan u humanim periapeksnim lezijama [5] i u inflamiranim marginalnim parodontalnim tkivima [6]. Podaci iz literature govore da je IL-6 multifunkcionalni citokin koga produkuje nekoliko tipova imunih ćelija - monociti, maktofagi, Th-2 limfociti, aktivirane B ćelije i polimorfonuklearne ćelije [7]. Produkcija IL-6 se odvija pod uticajem IL-1, TNF- $\alpha$ i INF- $\gamma$, međutim, on istovremeno reguliše sekreciju IL-1 i suprotstavlja se nekim njegovim efektima. IL-6 sekretuju i osteoblasti prilikom stimulisanja osteoklastne formacije. IL-6 stimuliše formiranje osteoklastnih prekursora i povećava broj osteoklasta in vivo, dovodeći do sistemskog pojačanja koštane resorpcije [8]. Zajedno sa TNF-a i IL-1, pripada grupi glavnih proinflamatornih citokina. Brojni podaci pokazuju da IL-6 poseduje i antiinflamatorne aktivnosti. Uloga IL-6 kao antiinflamatornog citokina posreduje kroz inhibitorne efekte TNF- $\alpha$ i IL-1 [9].

Cilj ove studije je bio da se odredi koncentracija IL-6 u homogenatima tkiva periapeksnih lezija i da se proveri korelacija sa simptomatologijom i veličinom lezija.

\section{MATERIJAL I METODE}

U istraživanje su bila uključena 93 pacijenta Klinike za stomatologiju Medicinskog fakulteta u Nišu kod kojih je kliničkim i radiografskim metodama postavljena dijagnoza hronične periapeksne lezije. Studija je odobrena od strane Etičkog odbora Medicinskog fakulteta u Nišu (br. 01-2066-5). Periapeksne lezije analizirane u studiji uzimane su sa korenova zuba koji su zbog nemogućnosti lečenja indikovani za ekstrakciju. Od svakog pacijenta su uzimani anamnestički podaci o toku i trajanju oboljenja, simptomatologiji, uzimanju lekova, a inspekcijom i palpacijom je utvrđeno eventualno postojanje lokalnog otoka ili otoka limfnih žlezda. Pored prisustva periapeksne lezije, uslov za uključenje pacijenata u studiju je bio da ne boluju od akutnih ili hroničnih oboljenja koja dovode do stanja imunodeficijencije i da u prethodna dva meseca nisu uzimali antibiotsku i antiinflamatornu terapiju. U istraživanje su uključivane periapeksne lezije onih zuba koji nisu pokazivali umeren ili ozbiljan oblik marginalnog parodontitisa.

Ispitivane lezije su prema subjektivnim simptomima pacijenata bile podeljene u dve grupe - simptomatske i asimptomatske lezije. Klinički su se simptomatske lezije karakterisale otokom, bolom, nelagodnošću pri žvakanju ili osetljivošću na perkusiju i palpaciju, dok asimptomatske lezije nisu pokazivale znake ili simptome akutnih periapeksnih oboljenja u vreme studije. Periapeksne lezije su merene milimetarskim lenjirom i u odnosu na veličinu podeljene $\mathrm{u}$ dve grupe: male $(\leq 5 \mathrm{~mm})$ i velike $(\geq 6 \mathrm{~mm})$ (Tabela 1). S obzirom na to da periapeksne lezije obuhvataju reaktivno tkivo koje se sastoji uglavnom od granulomatoznog inflamatornog tkiva koje zamenjuje normalnu kost, nije postojao pravi tkivni ekvivalent koji bi služio kao negativna kontrola.

Pre davanja lokalnog anestetika, zubi, gingiva i sluzokoža oko zuba su očišćeni $0,12 \%$ hlorheksidinom, a pacijent je ispirao usta $0,12 \%$ hlorheksidinom 30 sekundi. Uzorci periapeksnih lezija su odmah po ekstrakciji sterilnim skalpelom odstranjeni sa vrha korena zuba, isprani u sterilnom fiziološkom rastvoru, 
prosušeni na sterilnoj vati, stavljeni u sterilnu plastičnu ependorf epruvetu i zamrzavani na $-70^{\circ} \mathrm{C}$. Homogenizacija je vršena teflonskim tučkom u ledenom fosfatnom puferu $\mathrm{pH}$ 7,4 čija je zapremina prilagođena težini tkiva, tako da finalna koncentracija homogenata iznosi $10 \%$. Krupniji detritus je sedimentiran centrifugiranjem na 1400 obrtaja tokom 1 minuta na $-4^{\circ} \mathrm{C}$. Supernatant je nakon toga smrznut na $-70^{\circ} \mathrm{C}$ do izvođenja odgovarajućih biohemijskih analiza.

Koncentracija IL-6 je određivana ELISA testom (R\&D Systems Inc. Minneapolis, USA) prema uputstvu proizvođača. Senzitivnost ELISA testa za IL-6 je iznosila od 0,7 pg/ml, a koncentracija je analizirana u odnosu na simptomatologiju i veličinu lezije. Statistička analiza je urađena pomoću Mann-Whitney Rank Sum testa korišćenjem programa Sigmastat i Origin. Rezultati su izraženi kao srednje vrednosti \pm standardna devijacija. Statistički značajnim razlikama su smatrane one koje su bile pri $\mathrm{p}<0,05$.

\section{REZULTATI}

Ispitivanje koncentracije IL-6 u homogenatima uzoraka tkiva periapeksnih lezija je pokazalo značajnu koncentraciju citokina u svim uzorcima. Na Slici 1 prikazana je koncentracija IL-6 u homogenatima tkiva svih uzoraka, analiziranim u odnosu na simptomatologiju i veličinu. U grupi simptomatskih lezija prosečna koncentracija IL-6 je iznosila 975,51 pg/ml, dok je u grupi asimptomatskih lezija prosečna vrednost bila 212,04 pg/ml. Analizom koncentracija ustanovljeno je da postoji statistički značajno veća koncentracija IL-6 u simptomatskim lezijama ( $\mathrm{p}<0,001)$. U grupi velikih lezija prosečna koncentracija IL-6 je iznosila 687,14 $\mathrm{pg} / \mathrm{ml}$, dok je u grupi malih lezija prosečna vrednost bila 470,92 $\mathrm{pg} / \mathrm{ml}$. Razlika je postojala, ali nije bila statistički značajna.

U Tabeli 2 prikazane su vrednosti koncentracije IL-6 u okviru grupa simptomatskih i asimptomatskih lezija, a koncentracija citokina je u svakoj od grupa analizirana u odnosu na veličinu. Prosečna koncentracija IL-6 u simptomatskim velikim lezijama je iznosila 1162,40 pg/ml, dok je u simptomatskim malim lezijama koncentracija IL-6 iznosila 759,11 pg/ml. Nije zapažena statistički značajna razlika u koncentracijama IL-6 u grupi simptomatskih lezija u odnosu na veličinu. U grupi asimptomatskih lezija, takođe, nije ustanovljena statistički značajna koncentracija u odnosu na veličinu. Prosečna koncentracija IL-6 kod asimptomatskih velikih lezija je iznosila 189,24 pg/ml, dok je kod asimptomatskih malih lezija iznosila 232,86 pg/ml.

Na Slici 2 prikazana je koncentracija IL-6 u okviru grupa velikih i malih lezija, gde je statistička značajnost analizirana u odnosu na simptomatologiju. Prosečna koncentracija IL-6 kod velikih simptomatskih lezija je iznosila 1162,40 pg/ml, dok je kod velikih asimptomatskih iznosila 189,24 pg/ml. Ustanovljena razlika je bila statistički značajna $(\mathrm{p}<0,001)$. Analiza je pokazala i statistički značajno veću koncentraciju u malim simptomatskim lezijama $(759,11 \mathrm{pg} / \mathrm{ml})$ u odnosu na male asimptomatske $(232,86 \mathrm{pg} / \mathrm{ml})(\mathrm{p}<0,05)$.

\section{DISKUSIJA}

Periapeksne lezije nastaju kao rezultat perzistentnog inflamatornog odgovora indukovanog prolongiranom izloženošću periapeksnih tkiva mikroorganizmima kanala korena, što izaziva imunološku reakciju. U ovom lokalnom mehanizmu odbrane različiti inflamatorni medijatori igraju složenu i centralnu ulogu u regulisanju imunog odgovora. Dok proinflamatorni citokini, kao što su IL-1, IL-6, TNF- $\alpha$, TNF- $\beta$, hemokini i Th1 citokini, propagiraju inflamaciju u periapeksnim tkivima i aktiviraju osteoklastnu koštanu resorpciju $[10,11]$, uloga antiinflamatornih citokina je važna za supresiju inflamatornih procesa i procese zarastanja unutar periapeksnih lezija $[2,3,12]$.

U ranoj inflamatornoj kaskadi stvaranje IL-6 indukuju IL-1 i TNF- $\alpha$. IL-6 ima mnoge molekularne forme i svaki molekul ima drugačiju funkciju kada ga sekretuju različite ćelije u različitim situacijama. Nalaz da polimorfonuklearne ćelije u periapeksnim tkivima produkuju IL-6, što je navedeno od strane Eulera i saradnika [13], ukazuje da IL-6 može doprineti tkivnoj povredi na mestu inflamacije. IL-6 predstavlja integralni medijator $u$ akutnoj fazi odgovora na povredu i infekciju kada stimuliše ekspresiju proteina akutne faze [14]. Ispitivanje različitih citokina, kao što su TNF- $a$, IL-6, IL-3, GM-CSF, IL-11, IL-17, IL18 , na humanim i animalnim modelima pokazala su njihovu potencijalnu ulogu u patogenezi osteolitičkih oboljenja $[2,15]$. Dokazano je da inflamatorni citokini IL-6 i TNF-a imaju kapacitet da aktiviraju osteoklastnu koštanu resorpciju, a svoju ulogu mogu da ostvaruju sinergistički sa IL-1, izazivajući aktivaciju ili diferencijaciju osteoklasta i produkciju, odnosno sekreciju prostaglandina od strane brojnih ćelijskih tipova, uključujući fibroblaste i osteoblaste [2]. Više autora je objavilo ekspresiju IL-6 u humanim periapeksnim granulomima i cistama. Rezultati ove studije su dokazali prisustvo IL-6 u svim tkivnim uzorcima periapeksnih lezija, što je u skladu sa podacima iz literature $[9,16]$.

Istraživanja su pokazala da je nivo IL-6 značajno povećan kod infekcija i bolnih stanja. U studiji De Jongh i saradnika [17] važna uloga je pripisana IL-6 u patofiziologiji bola. Zbog te činjenice, u ovoj studiji je analizirana korelacija između nivoa IL-6 i simptomatologije. Rezultati ovog istraživanja su ukazali na statistički značajno veću produkciju IL-6 u simptomatskim lezijama u odnosu na asimptomatske, dok je prosečna koncentracija ovog citokina bila veća u velikim lezijama u odnosu na male, ali ova razlika nije bila statistički značajna.

U istraživanju Gazivode i saradnika [18] uočena je jača produkcija IL-6 u simptomatskim i velikim lezijama, naglašavajući pre svega njegov proinflamatorni aspekt u ovom oboljenju. Međutim, eksperimenti na IL- 6 deficitnom mišu pokazuju suprotne rezultate, ukazujući na efekat zaštite ovog citokina od koštane destrukcije [14]. Ove razlike mogu se objasniti činjenicom da IL-6 poseduje i proinflamatorne i antiinflamatorne osobine i da njegov krajnji efekat zavisi od ciljnih ćelija i sadejstva drugih citokina.

Inflamatorne reakcije kod pacijenata sa apeksnim parodontitima nisu ograničene samo na periradiksnu regiju [19]. Poznato je da dentalne infekcije mogu imati negativni uticaj na opšte zdravlje kod pacijenata sa rizikom [20]. Analiza krvi pacijenata nakon endodontske terapije zuba sa apeksnim parodontitima je pokazala prisustvo bakterija za koje je dokazano da vode poreklo iz kanala korena [21]. Širenje oralnih bakterija putem krvotoka nije jedini put za posredovanje u ciljanim efektima oralnih fokalnih infekcija. Mnogo značajniji uticaj na funkciju udaljenih tkiva i organa može biti izazvan pojedinim citokinima. Iako većina članova superfamilije citokina ispoljava kratkotrajne efekte, IL-1, IL-6 i TNF su pokazali da, lokalno produkovani unutar tkiva periapeksnih granuloma, mogu biti nošeni putem krvotoka do udaljenih mesta. Ovi citokini mogu 
da izazovu akutnu fazu odgovora koji podrazumeva povišenu telesnu temperaturu, povećanu sedimentaciju eritrocita i promenu u serumskim proteinima sintetisanih od strane hepatocita. Pojedini autori su pratili povećane nivoe proteina akutne faze kod pacijenata sa hroničnim periapeksnim granulomima. Njihov nivo je snižen na normalne vrednosti nakon hirurškog uklanjanja lezije apikotomijom [10,22].

\section{ZAKLJUČAK}

Veća koncentracija IL-6 u lezijama sa izraženim kliničkim simptomima, kao i velikim lezijama, ukazuje na njegovu važnu proinflamatornu aktivnost i ključnu ulogu snažnog medijatora koji je odgovoran za progresiju lezije i stimulaciju koštane resorpcije u patogenezi periapeksnih lezija. 